\title{
IMPROVING PRODUCTIVITY OF BANATY GRAPEVINES BY FOLIAR APPLICATION OF BORON, MAGNESIUM AND ZINC
}

\author{
A.M. Hegazy, A.A. Kassem, A.E. Hassan and G.M. El-Hagen \\ Hort. Dept., Fac. of Agric., Menoufia University. \\ Received: Mar. 7, 2018 \\ Accepted: Mar. 29, 2018
}

\begin{abstract}
This investigation was carried out during 2015 and 2016 seasons on cane trained Thompson seedless grapevines grown in a private vineyard located at ElShuhadaa district, Menoufia Governorate. The vineyard soil texture is clay loam. The selected vines are planted at $2 \times 3$ meters apart. Pruning was conduced on the first week of Jan. in both seasons leaving 64 eyes per vine (4 fruiting canes $\times 14$ eyes plus four replacement spurs $\times$ two eyes). This study was initiated for elucidating the effect of single or combined application of boric acid, magnesium sulphate and chelated $-\mathrm{Zn}$ on the main shoot length, leaf area, berry setting percentage, yield and as well as physical and chemical properties of Thompson Seedless grapes. Selecting the best treatment that responsible for producing filled clusters and higher productivity quantitively and qualitatively is considered another target . Results showed that spraying boric acid at $0.05 \%$, chelated $-\mathrm{Zn}$ at $0.05 \%$ and magnesium sulphate at $0.5 \%$ ascending order was very effective in enhancing the leaf area, berry setting, yield and quality of the berries . The best results were obtained with using the three nutrients together .

For producing filled clusters and improving yield quantitively and qualitatively of Thompson seedless grapevines, it is necessary to spray vines with boric acid at $0.05 \%$, chelated $-Z n$ at $0.05 \%$ and magnesium sulphate at $0.5 \%$ four times at the growth start, first bloom , just after berry setting and at one month later.
\end{abstract}

Key words: Grapevine, Thompson seedless, Zinc, Magnesium , Boron

\section{INTRODUCTION}

The old world species Vitis vinifera L. is the grape of antiquity often mentioned in the Bible. Most table, wine and raisin grapes are produced from varieties of such species. It originated in the regions between and south of the Caspian and Black seas in Asia Minor. It has been carried from region to region by civilized man in all temperate climates. Recently it has been grown more in subtropical climates. Several thousands, varieties of grapes have been derived from this species . Vinifera is also a parent of many hybrid grapes in Eastern America, as breeders in this region desired to introduce some of the qualities of Vitis vinifera into their grapes ( Winkler, 1965 and Weaver , 1976 ). The importance of grapes as agricultural crop in general and as fruit crop, in particular, is doubtless when it cultivated area and its production of fruits are concerned. It is considered the first major fruit crop allover the world (Bacha 1984 and F.A.O., 2016). Grapes are cultivated on approximately 9.575 Million ha worldwide with a total world production of over 70.58 Million tons of fruits per year (F.A.O., 2016) . Table grapes have been grown in European and Mediterranean basin countries as Italy, France, Portugal, Spain, Greece, Turkey, Egypt and Syria, also U.S.A. , China, South Africa and Argentina. In addition, table grapes have been grown in Tropical lowland areas of such countries as Thailand, Indonesia, Philippines, India, Srilanka and Malaysia (Chapman, 1990) . A considerable part of Egyptian vineyards usually suffer from 
the deficiency of most macro and micro nutrients due to the great depletion and exhaustion of these nutrients by vines as well as the neglection of their use by growers. The nutritional status of vines plays an important role in the dynamic activities of metabolism. When this phenomenon if left without relieving it causes a dangerous disturbance in the physiological activities of grapevines that reflects in producing lower yield or $I$ and poor fruit quality (Strakov and Kolyaukovskii , 1989) . Macronutrients especially $\mathrm{Mg}$ as well as micronutrients namely $\mathrm{Zn}$ and $\mathrm{B}$ play a key role in the nutrition of the fruit crops especially grapevines.

The present study aimed to throw some lights on the effect of foliar application of boron, magnesium and zinc on the vegetative growth, percentage of berry setting, yield, as well as physical and chemical properties of Thompson seedless grapes.

\section{MATERIALS AND METHODS}

This study was carried out during 2015 and 2016 seasons on fourty-eight uniform in vigour 13- years old cane trained Thompson seedless grapevines grown in a private vineyard located at ElShuhadaa, Menoufia Governorate. The vineyard soil is clay loam and well drained and with a water table not less two meters deep. Winter pruning by using cane pruning system was carried out on first week of Jan. in both seasons leaving 64 eyes ( 4 fruiting canes $\times 14$ eyes plus four replacement spurs $x$ two eyes ) vine load for all the selected grapevines. The selected vines are planted at $2 \mathrm{~m} \times 3 \mathrm{~m}$ apart. Surface irrigation system was followed as shown in Table (1).

\section{1- Soil Analysis:}

Mechanical, physical and chemical analysis of the tested soil were carried out at the start of the experiment according to the procedures of Chapman and Pratt (1965) and Black et al., (1965) .

\section{2- Experimental work :}

The experiment involved the following eight treatments from single and combined application of three nutrients namely boron, magnesium and zinc in addition to the control treatment:

1- Control (sprayed with water).

2- Spraying chelated zinc at $0.05 \%(0.5$ g/L).

3- Spraying boric acid at $0.05 \%$ ( $0.5 \mathrm{~g} / \mathrm{L}$ ).

4- Spraying magnesium sulphate at $0.5 \%$ (5.0 g/L).

5- Spraying chelated $\mathrm{Zn}+$ boric acid at same previous concentrations.

6- Spraying chelated $\mathrm{Zn}$ +magnesium sulphat at the same previous concentrations.

7- Spraying boric acid + magnesium sulphate at the same previous concentrations.

8- Spraying chelated $\mathrm{Zn}+$ boric acid +magnesium sulphat at the same previous concentrations.

Each treatment was replicated three times, two vines per each. Boric acid (17\% B); magnesium sulphate $(9.6 \% \mathrm{Mg})$ and Chelated-Zinc $(14 \% \quad \mathrm{Zn})$ at the recommended concentration namely $0.05, \quad 0.5$ and $0.05 \%$, respectively (according to Abd EL-Hady, 1995) was sprayed four times at growth start $\left(2^{\text {nd }}\right.$ week of March), just before first bloom $\left(1^{\text {st }}\right.$ week of April ), Just after berry setting ( $2^{\text {nd }}$ week of May), and at one month later ( $2^{\text {nd }}$ week of June). Triton B as a wetting agent was added at $0.05 \%$ to all treatments including the control treatment. Spraying was conducted till runoff ( 5 liters per vine).

\section{3- Experimental design:}

Complete randomized block design was followed. 
Table (1): particles size distribution and chemical analysis of soil sample from the experimental sites

\begin{tabular}{|c|c|c|c|c|}
\hline \multicolumn{2}{|c|}{ Particle size distribution } & \multicolumn{3}{|c|}{ Chemical Analysis } \\
\hline Clay \% & 38.92 & $\mathrm{PH}(60-90 \mathrm{~cm})$ & 7.95 & \\
\hline Silt \% & 31.09 & $E C$ dsm $^{-1}$ & 032 & \\
\hline Fine sand \% & 24.25 & $\mathrm{CaCO}_{3}$ & 0.32 & \\
\hline Coarse sand \% & 3.16 & O.M \% & 0.06 & \\
\hline \multirow[t]{3}{*}{ Texture class } & clay loam & \multirow{3}{*}{ Available nutrients(ppm) } & B & 6 \\
\hline & & & $\mathrm{Zn}$ & 20 \\
\hline & & & Mg & 0.15 \\
\hline
\end{tabular}

4- Common horticultural practices:

Except those dealing with the present treatments, all the selected vines (48 vines) received the usual horticultural practices which are common used in the vineyard.

\section{5- Different measurements:}

\section{5-1- Averages main shoot length and} leaf area $\left(\mathrm{cm}^{2}\right)$ :

Ten main shoots were selected from each vine for measuring shoot length $\left(1^{\text {st }}\right.$ week of July). At the same time, twenty mature leaves per vine were picked from those leaves opposite to the first clusters on each shoot (Summer, 1985) and the leaf area was estimated according to the following equation reported by (Ahmed and Morsy 1999).

$$
\mathrm{La}=\mathbf{0 . 4 0}(0.79 \times \mathrm{w} 2)+15.23
$$

Where La= Leaf area $\left(\mathrm{cm}^{2}\right)$ and $W$ was the maximum width of leaf $(\mathrm{cm})$.

\section{5-2- Measurements of berry set \% :-}

It was calculated by caging five clusters per each vine in perforated white paper bags before bloom. After setting of all berries in each cluster, The bags were removed for counting of :

a) The number of attached berries.

b) The number of dropped berries. c) The number of dropped flowers.

d) The number of total flowers $(a+b+c)$ per cluster.

Berry set \% was estimated by dividing number of attached berries by total number of flowers per cluster and multiplying the product by 100 .

\section{5-3- Measurements of yield :}

Harvesting took place when T. S. S I acid ratio in the berries of the check treatment reached at last $25: 1$ (at the last week of July in both seasons). The yield of each vine was recorded in terms of weight (in $\mathrm{Kg}$ ) and number of clusters per vine then the average weight of cluster was recorded ( $g$ ).

\section{5- 4- Berries quality :}

Five clusters from each vine were taken at random for determination of the following chemical characters :

1- Percentage of total soluble solids in the juice by handy refractometer.

2- Percentage of total acidity (as $g$ tartaric acid $/ 100 \mathrm{ml}$ juice) by titration $\begin{array}{lllll}\text { against } & 0.1 & \mathrm{Na} & \mathrm{OH} & \text { using }\end{array}$ phenolphthalein as an indicator (A.O.A.C., 1985) .

\section{6- Statistical analysis :-}


All the obtained data were tabulated and statistically analyzed using New L.S.D at $5 \%$ for made all comparisons among the investigated treatment means according to (mead et al., 1993) .

\section{RESULTS AND DISCUSSION}

\section{1- Effect foliar application of boric}

acid, magnesium sulphate and chelated $-\mathrm{Zn}$ on the main shoot length and leaf area :

Data concerning the effect of foliar application of boric acid, magnesium sulphate and chelated. $\mathrm{Zn}$ on the, main shoat length and leaf area of Thompson Seedless grapevines during 2015 and 2016 seasons are shown in Table (2). It is clear from the obtained data that single or combined application of chelated- $\mathrm{Zn}$ at $0.05 \%$, boric acid of $0.05 \%$ and magnesium sulphate at $0.5 \%$ significantly stimulated main shoot length and the leaf area compared with check treatment. Spraying boric acid at $0.05 \%$, chelated $\mathrm{Zn}$ at $\mathbf{0 . 0 5 \%}$ and magnesium sulphate at $0.5 \%$, in ascending order was favorable in stimulating the two growth characters. Double or triple application of these nutrients was significantly very effective in enhancing main shoot length and leaf area compared to the use of each nutrient alone. Significant differences on main shoot length and leaf area were detected among all treatments. The maximum main shoot length and leaf area were recorded on the vines received the three nutrients together, as leaf area reached 160.2 and $162.3 \mathrm{~cm}^{2}$ in both seasons, respectively. The minimum values $\left(133.2\right.$ and $141.1 \mathrm{~cm}^{2}$ in the both seasons, respectively were recorded on untreated vines.

The outstanding effect of boron on controlling water, activating the formation of meristems, encouraging cell development and the elongation of cells and root development as well as enhancing the biosynthesis and movement of sugars and IAA which reflected in improving growth could explain the present results (Adriano , 1985). The stimulating effect of boron on growth characters was supported by the results of Ahmed and Abd El-Hameed (2003) and Mohamed-Nermean (2009) on Red Roomy grapevines and Farahat (2008) on Red Globle grapevines .

Table (2): Effect of foliar application of boric acid, Chelated- $\mathrm{Zn}$ and magnesium sulphate on the main shoot length $(\mathrm{cm})$ and leaf area $\left(\mathrm{cm}^{2}\right)$ of Thompson seedless grapevines during 2015 and 2016 seasons

\begin{tabular}{|l|c|c|c|c|}
\hline \multirow{2}{*}{\multicolumn{2}{|c|}{ Treatment }} & \multicolumn{2}{c|}{$\begin{array}{c}\text { Main shoot length } \\
(\mathrm{cm})\end{array}$} & \multicolumn{2}{c|}{ Leaf area $\left(\mathrm{cm}^{2}\right)$} \\
\cline { 2 - 5 } & 2015 & 2016 & 2015 & 2016 \\
\hline 1 - Control & 83.1 & 86.2 & 133.2 & 141.1 \\
\hline 2 - Chelated - Zn at 0.05\% & 86.1 & 94.6 & 139.0 & 147.2 \\
\hline 3 - Boric acid at 0.05\% & 84.2 & 90.2 & 136.0 & 144.9 \\
\hline 4 - Magnesium sulphate at 0.5\% & 90.3 & 98.1 & 143.3 & 150.3 \\
\hline 5 - Zn + B & 94.2 & 103.2 & 146.4 & 153.4 \\
\hline 6 - Zn + Mg & 100.1 & 109.1 & 154.1 & 159.3 \\
\hline $7-\mathrm{B}+\mathrm{Mg}$ & 97.2 & 107.2 & 151.1 & 157.1 \\
\hline 8 - Zn + B + Mg & 104.3 & 115.9 & 160.2 & 162.3 \\
\hline
\end{tabular}


Improving productivity of banaty grapevines by foliar application of ............

\begin{tabular}{|l|l|l||l|l|}
\hline New L. S. D. at 5\% & 1.8 & 2.0 & 1.9 & 2.1 \\
\hline
\end{tabular}

The great stimulation on these growth aspects in relation to application of magnesium might be attributed to its effect in enhancing the formation of carbohydrates and the transport of $P$ from roots to vegetative portions (Nijjar, 1985). These results with respect to the stimulating effect of magnesium on the main shoot length and leaf area are in approval with those obtained by Ahmed and Abd El-Hameed (2003) ; MohamedNermean (2009) on Red Roomy grapevines ; Gobara et al. , (2001) on Banaty grapevines and Kamel (2002) on Flame seedless grapevines.

The important of Zinc on stimulating growth characters might be attributed to its effect in enhancing the biosynthesis of most organic foods and the natural hormone namely IAA as well as activating cell division, cell enlargement as well as water and nutrient transport (Mengel , 1985) . The stimulating effect of Zinc on the leaf area was confirmed by the results of Gobara et al., (2002) ; Madian (2004) and Mohamed-Nermean (2009) on Red Roomy grapevines. The results of Gobara (1999) who worked on Flame seedless grapevines supported the present results.

\section{2- Effect of foliar application of} boric acid, magnesium sulphate and chelated $-\mathrm{Zn}$ on the percentage of berry setting:

Values of percentage of berry setting of Thompson Seedless grapevines during 2015 and 2016 seasons in relation to foliar application of boric acid, magnesium sulphate and chelated $-\mathrm{Zn}$ are shown in Table (3).

It is evident from the obtained data that percentage of berry setting was significantly varied among the boron, magnesium and zinc treatments. It was significantly improved with using boric acid, magnesium sulphate and chelated -Zn either applied singly or used in different combinations rather than nonapplication. The highest values were presented in the vines treated with boric acid, chelated - $\mathrm{Zn}$ and magnesium sulphate , in ascending order. Combined application of these nutrients was preferable than using each nutrient alone in enhancing percentages of berry setting. Application of the three nutrients together significantly surpassed the application of two elements in enhancing such percentage. Significant differences on percentage of berry setting were observed among all nutrient treatments . The maximum values were recorded on the vines received the three nutrients together. Percentages of berry setting reached $9.29 \%$ and $8.54 \%$ in the vines treated with such promised treatment compared to $4.95 \%$ and $5.12 \%$ produced by untreated vines in both seasons, respectively .

The beneficial effect of boron on the biosynthesis and translocation of carbohydrates as well as nitrogen metabolism and enhancing germination of pollens could result in improving berry setting .

The results regarding the improving effect of boron on berry setting are in harmony with those obtained by Mohamed-Nermean (2009) on Red Roomy grapevines and Farahat (2008) on Red Globle grapevines.

The effect of magnesium in enhancing growth characters and vine nutritional status could result in increasing the availability of mineral and organic foods to flowers .

The promoting effect of magnesium on berry setting was confirmed by the results of Ahmed and Abd El-Hameed (2003) on Red Roomy grapevines ; 
Gobara et al.,, (2001) on Thompson seedless grapevines and Zaki (2006) on Superior grapevines.

Table (3): Effect of foliar application of boric acid, Chelated - $\mathrm{Zn}$ and magnesium sulphate on the percentage of berry setting and numbers of clusters per vine of Thompson seedless grapevines during 2015 and 2016 seasons.

\begin{tabular}{|l|c|c|c|c|}
\hline \multirow{2}{*}{\multicolumn{1}{|c|}{ Treatment }} & \multicolumn{2}{c|}{ Berry setting (\%) } & \multicolumn{2}{c|}{$\begin{array}{c}\text { No. clusters per vine } \\
\text { (\%) }\end{array}$} \\
\cline { 2 - 5 } & 2015 & 2016 & 2015 & 2016 \\
\hline 1 - Control & 4.95 & 5.12 & 25.0 & 25.0 \\
\hline 2 - Chelated - Zn at 0.05\% & 6.43 & 6.19 & 26.0 & 28.0 \\
\hline 3 - Boric acid at 0.05\% & 5.65 & 5.66 & 25.0 & 26.0 \\
\hline 4 - Magnesium sulphate at 0.5\% & 7.10 & 6.72 & 26.0 & 29.0 \\
\hline 5 - Zn + B & 7.79 & 7.31 & 26.0 & 30.0 \\
\hline 6 - Zn + Mg & 8.61 & 8.01 & 26.0 & 32.0 \\
\hline 7 - B + Mg & 8.53 & 7.89 & 26.0 & 31.0 \\
\hline 8 - Zn + B + Mg & 9.29 & 8.54 & 26.0 & 33.0 \\
\hline New L. S. D. at 5\% & 0.60 & 0.55 & N.S. & 1.1 \\
\hline
\end{tabular}

The great increase on berry setting due to spraying zinc might be attributed to its influence on increasing the biosynthesis of organic foods and IAA as well as enhancing the movement of water and nutrients (Nijjar , 1985). The previously mentioned effect of zinc on improving growth and vine nutritional status surely reflected on amending the flowers with their requirements from organic and mineral foods, consequently increased the retained grapes.

The promoting effect of zinc on berry setting was supported by the results of Mohamed-Nermean (2009) on Red Roomy grapevines and Gobara (1999) on Flame seedless grapevines.

\section{4- Effect of foliar application of boric acid , magnesium}

sulphate and chelated-Zn on the yield and cluster weight :

Data concerning the effect of foliar application of boric acid , magnesium sulphate and chelated $-\mathrm{Zn}$ on number of clusters per vine, yield per vine and cluster weight of Thompson seedless grapevine during 2015 and 2016 seasons are shown in Tables (3 and 4) .

It is noticed from the obtained data that single or combined application of chelated $-\mathrm{Zn}$, boric acid and magnesium sulphate had no significant effect on the number of clusters per vine in the first season of study and significantly improved the yield expressed in weight and number of clustered per vine (in the second season) and cluster weight and dimensions (length and width) rather than the check treatment. Spraying the vines four times with boric acid at $0.05 \%$, 
chelated-zn at $0.05 \%$ and magnesium sulphate at $0.5 \%$, in ascending order was very effective in improving the yield as well as cluster weight and dimensions. Combined application of these nutrients was preferable in improving yield as well as cluster weight and dimensions than using each nutrient alone. Significant differences on these parameters were observed among the eight nutrient treatments. The best results with regard to yield were obtained in the vines treated with boric acid, chelated $-\mathrm{Zn}$ and magnesium sulphate together. Yield per vine under application of such promised treatment reached 12.72 and $15.66 \mathrm{~kg}$ compared with 7.62 and 7.99 for untreated vines, in both seasons, respectively.

The heaviest cluster borne in vines treated with boron treatments were attributed to either important role in enhancing berry set as well as berry weight and dimensions.

The beneficial effect of boron on the yield might be attributed to their important roles in stimulating growth characters, nutritional status of the vines, berry set, number of clusters per vine and weight of cluster and berry.
These results concerning the improving effect of boron on yield and cluster weight are in agreement with those obtained by Mohamed-Nermean (2009) on Red Roomy grapevines; Zaki (2006) on Superior grapevines and Farahat (2008) on Red Globle grapevines.

The promoting effect of magnesium on berry setting, cluster weight and number of clusters surely reflected in increasing the yield.

The promoting effect of magnesium on the yield and cluster weight was confirmed by the results of MohamedNermean (2009) on Red Roomy grapevines ; Gobara et al.,(2001) on Thompson seedless grapevines, Kamal (2002) on Flame seedless grapevines and Zaki (2006) on Superior grapevines .

The increment on the yield owing to using zinc might be attributed to its effect in stimulating growth, vine nutritional status, berry set, number of clusters as well as weights of berry and cluster.

The results regarding the beneficial effect of zinc on the yield and cluster weight are in harmony with those obtained by Madian (2004) and Amin (2007) on Red Roomy grapevines and Mansour et al., (2000) on White Banaty grapevines.

Table (4): Effect of foliar application of boric acid, Chelated - $\mathrm{Zn}$ and magnesium sulphate on the yield per vine $(\mathrm{kg})$ and cluster weight $(\mathrm{g})$ of Thompson seedless grapevines during 2015 and 2016 seasons.

\begin{tabular}{|l|c|c|c|c|}
\hline \multirow{2}{*}{ Treatment } & \multicolumn{2}{|c|}{ Yield vine (kg) } & \multicolumn{2}{c|}{ Cluster weight (g) } \\
\cline { 2 - 5 } & 2015 & 2016 & 2015 & 2016 \\
\hline 1 - Control & 7.62 & 7.99 & 304.9 & 319.8 \\
\hline 2 - Chelated - Zn at 0.05\% & 8.99 & 10.0 .2 & 354.8 & 357.7 \\
\hline 3 - Boric acid at 0.05\% & 8.25 & 8.80 & 329.8 & 338.5 \\
\hline 4 - Magnesium sulphate at 0.5\% & 9.87 & 11.15 & 379.6 & 384.4 \\
\hline $5-$ Zn + B & 10.66 & 12.23 & 410.1 & 407.8 \\
\hline $6-\mathrm{Zn}+\mathrm{Mg}$ & 12.04 & 14.46 & 462.9 & 451.9 \\
\hline $7-\mathrm{B}+\mathrm{Mg}$ & 11.43 & 13.32 & 439.8 & 429.7 \\
\hline
\end{tabular}


A.M. Hegazy, et al.,

\begin{tabular}{|l|c|c|c|c|}
\hline $8-\mathrm{Zn}+\mathrm{B}+\mathrm{Mg}$ & 12.72 & 15.66 & 489.2 & 474.5 \\
\hline New L. S. D. at 5\% & 0.75 & 0.84 & 18.95 & 18.95 \\
\hline
\end{tabular}

5- Effect of foliar application of boric acid, magnesium sulphate and chelated-Zn on some chemical characters of the grapes :

Data regarding the effect of foliar application of boric acid, magnesium sulphate and chelated $-\mathrm{Zn}$ on percentages of total solids and total acidity of Thompson seedless grapevine during 2015 and 2016 seasons are shown in Table (5) . Single or combined application of boric acid, magnesium sulphate and chelated-Zn significantly was responsible for improving chemical properties of the grapes in terms of increasing total soluble solids and decreasing total acidity compared to the control treatment. The promotion on fruit quality was associated with using boric acid, chelated $-\mathrm{Zn}$ and magnesium sulphate, in ascending order. Combined applications of these nutrients was superior the application of each nutrient alone in improving chemical characters of the grapes. Fruit quality was significantly affected by varying nutrient treatments. The best results with regard to quality of the grapes were obtained on the vines that sprayed four times with boric acid, chelated $-\mathrm{Zn}$ and magnesium sulphate. Unfavorable results were recorded on untreated vines. Similar results were announced in both the two experimental seasons.

The great important of boron on the biosynthesis and translocation of sugars could result in accumulated more sugars in the berries and highly advanced maturity stage and improved quality of the berries. The results with regard to improving effect of boron on chemical characters of the berries are in concordance with those obtained by Farahat (2008) on Red Globle grapes.

The improving effect of magnesium sulphate on fruit quality might be attributed to its effect on enhancing plant pigments formation, building carbohydrates and activating the uptake op $P$ and different enzymes involved in fruit maturity ( Nijjar, 1985). The results with regard to the promoting effect magnesium on chemical characters of the grapes are in concordance with those obtained by Zaki (2006) on Superior grapes.

Table (5): Effect of foliar application of boric acid, Chelated - $\mathrm{Zn}$ and magnesium sulphate on the percentage of total soluble solids and total acidity of Thompson seedless grapevines during 2015 and 2016 seasons.

\begin{tabular}{|l|c|c|c|c|}
\hline \multirow{2}{*}{ Treatment } & \multicolumn{2}{|c|}{ T.S.S \% } & \multicolumn{2}{c|}{ Total acidity \% } \\
\cline { 2 - 5 } & 2015 & 2016 & 2015 & 2016 \\
\hline 1 - Control & 19.6 & 20.1 & 0.531 & 0.550 \\
\hline 2 - Chelated - Zn at 0.05\% & 20.2 & 21.1 & 0.484 & 0.510 \\
\hline 3 - Boric acid at 0.05\% & 19.9 & 20.6 & 0.509 & 0.530 \\
\hline 4 - Magnesium sulphate at 0.5\% & 20.5 & 21.6 & 0.462 & 0.490 \\
\hline 5 - Zn + B & 20.9 & 21.9 & 0.440 & 0.470 \\
\hline 6 - Zn + Mg & 21.5 & 22.7 & 0.400 & 0.440 \\
\hline 7 - B + Mg & 21.2 & 22.3 & 0.420 & 0.450 \\
\hline
\end{tabular}




\begin{tabular}{|l|c|c|c|c|}
\hline $8-\mathrm{Zn}+\mathrm{B}+\mathrm{Mg}$ & 21.9 & 23.0 & 0.390 & 0.420 \\
\hline New L. S. D. at 5\% & 0.25 & 0.34 & 0.024 & 0.022 \\
\hline
\end{tabular}

The present results regarding the effect of zinc on improving quality of the grapes might be attributed to its effect in biosynthesis and translocation of carbohydrates (Nijjar, 1985). The remarkable promotion on physical and chemical characters of grapes owing to using zinc was supported by the results of Madian (2004) on Red Roomy grapes and Mohamed-Nermean (2009) on Early Superior grapes.

\section{REFERENCES}

Abd El-Hady, A. M. (1995). Response of Roomy grapevines to foliar sprays of urea and boron. Ph. D. Thesis Fac. of Agric. Minia Univ.

Adriano, D. C. (1985). Trace Elements in the Terrestrial Environment Springer Vrtlag, New York, pp 20-40 .

Ahmed, A. M. and H. M. Abd El-Hameed (2003). Growth, uptake of Some nutrients and productively of Red Roomy vines as affected by spraying of some amino acids, magnesium and boron. Minia J. of Agric. Res \& Develop. 23(4): 649-666.

Ahmed, F. F. and M. H. Morsy (1999). A new method for measuring leaf area in different fruit species. Minia J. Agric. Res. \& Dev. Vol. (19) pp 99-105.

Amin, M. M. A. (2007). Response of Red Roomy grapevines to application of amino acids and some micronutrients. M. Sc. Thesis, Fac. of Agric. , Minia Univ.

Association of Official Agricultural Chemists (A.O.A.C.) (1985). Official methods of Analysis $14^{\text {th }}$ ed. A.O.A.C. , Benjamin Franklin Station Washington, D.C., U.S.A. pp 490-510 .

Bacha, M. A. A. (1984). Fundamentals of Fruit Trees. Dar El-Matbut, El-Gadida, pp. 227-316.

Black, G.A., D.D. Evans, L.E. Ersminger, J.L. White and F.E. Clark (1965).
Methods of Soil Analysis. Am. Soc. Agric. Inc. Bull. Madison, Washington, U.S.A., pp 891-1400 .

Chapman, H.D. and P. F. Pratt (1965). Methods of Analysis for Soil , Plants and Water. Univ. of California , Division of Agric . , Sci. PP 172-173.

Chapman, K.R. (1990). Table grapes in the Tropics Areas for Research and Market Opportunities. Acta Horticulture : III International Workshop on Temperate Zone Fruits in the Tropics and Subtropics 279: 9196.

Farahat, I.A.M. (2008). Effect of some antioxidants and boron treatments on growth and fruiting of Red Globe grapevines. M. Sc. Thesis, Fac. of Agric. , Minia Univ.

Food Agriculture Organization (F.A.O.) (2016). Quarterly Bulletin of Statistics 8, No (112): 31. Year Annuario Production , 45.

Gobara, A.A. (1999). Behavior of Flame Seedless grapevines to fertilization with some nutrients and vine load. J. Agric. Sci. , Mansoura Univ. , 24(3) : 1309-1331.

Gobara, A. A., F.F. Ahmed and M.S. ElShamaa (2001). Effect of varying $N, K$ and $\mathrm{Mg}$ application ratios on growth , leaf chemical composition and productivity of Banaty grapevines. The Fifth Arabian Hort. Conf. Ismailia , Egypt . March 24-28, 83-90 .

Gobara, A. A., A.M. Akl, A.M. Wassel and M.A. Abada (2002). Effect of yeast and some micronutrients on the yield and quality of Red Roomy grapevines. $2^{\text {nd }}$ Inter Conf. Hort. Sci. Kafr El-Sheikh , Tanta Univ. , Egypt . PP 709-719 .

Kamel, M.K. (2002). Physiological studies on pruning and fertilization of Flame Seedless grapevines (Vitis ninifera L.). Ph.D. Thesis . Fac. of Agric. , Minia Univ. 
Madian, A.M. (2004). Response of Red Roomy grapevines to spraying with some micronutrients and antioxidants. M.Sc. Thesis , Fac. of Agric. , Minia Univ.

Mansour, A. E. M., F. F. Ahmed, A. H. Ali and Mervet M. Ali (2000). The synergistic influence of using some micronutrients with ascorbic acid on yield and quality of Banaty grapevines. The $2^{\text {nd }}$ Sci. Conf. of Agric. Sci. Assiut, Egypt Oct. pp 309316.

Mead, R., R. N. Currnow and A. M. Harted (1993). Statistical Methods in Agricultural and Experimental Biology. Second Ed. Chapman, Hall London. Pp 10 - 44 .

Mengel, K. (1985). Dynamics and availability of major nutrients in soils . Advances in Soil Sci. , Vol. 2 , Springer -Verlag New York, pp 89-91.

Mohamed - Nermean, A. H. (2009): Response of Red Roomy grapevines to foliar application of boron , magnesium and zinc. M. Sc. Thesis, Fac. of Agric. , Minia Univ.

Nijjar, G. S. (1985). Nutrition of Fruit Trees. In: "Fertilizer and Manures" (Eds. Kumar, U.R.), Kilyani Press, New Delhi , India , pp 206-234.

Strakov, V.G. and A.S. Kolyaukovskii (1989). Trace Element Fertilizer Application in Vineyards . Rastenii Kishiner, Maldavian SSR Zhurnal, pp 153-160 .

Summer, M.E. (1985). Diagnosis and Recommendation Integrated System (DRIS) as a guide to orchard fertilization . Hort. Abst. 55(8): 7502.

Weaver, R. J. (1976). Grape Growing . Freeman and Company San Francesco, U.S.A. pp 60-95 .

Winkler, A. J. (1965). General Viticulture. Univ. of California Press, Berkely and Los Angeles . pp 40-55.

Zaki, A. S. (2006). Some techniques for improving the quality of Superior grapes . M. Sc. Thesis, Fac. of Agric. Minia Univ. 
تحسين انتاجية العنب البناتى بالرش الورقى بالبورون والمغتيسيوم والزنك

عاطف محمد حجازى ، أحمد على قاسم ، عبد الله السيد حسن ، غباثى محمود الهجين قسم البساتين - كلية الزراعة - جامعة المنوفية

الملخص العربي

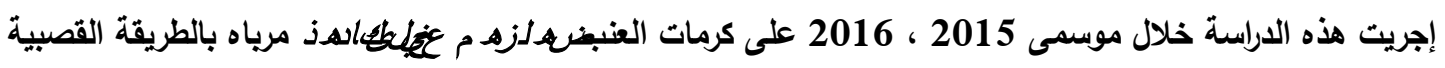

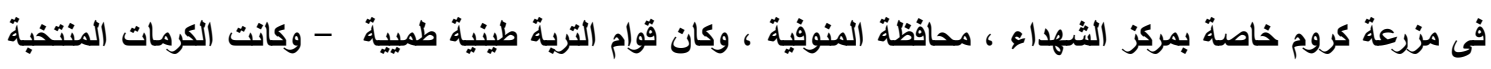

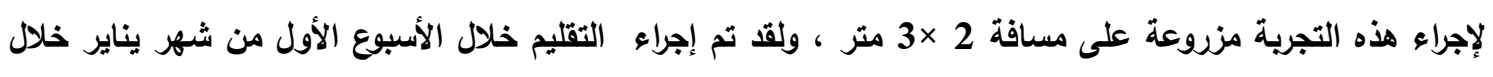

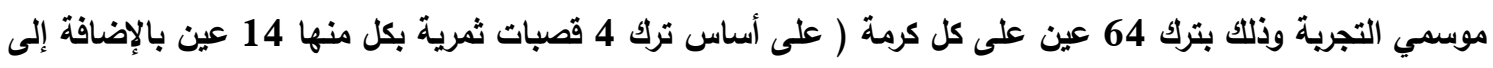

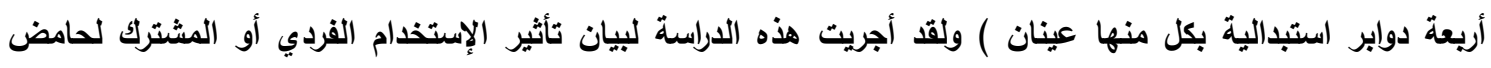

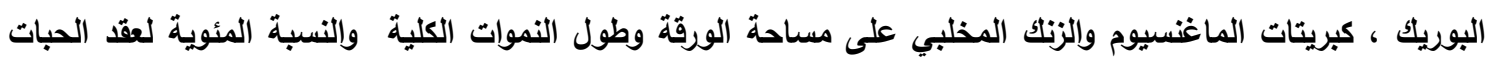

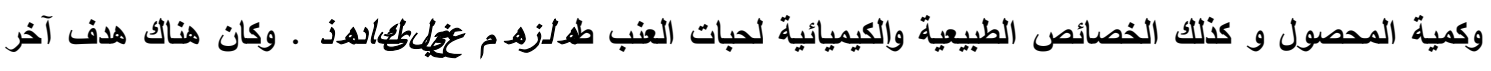

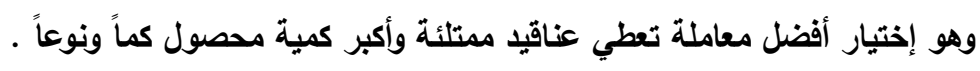

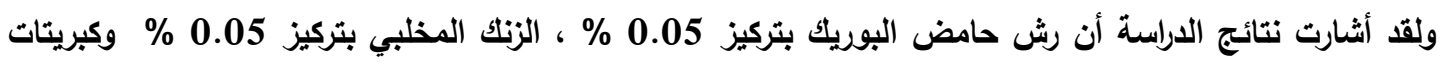

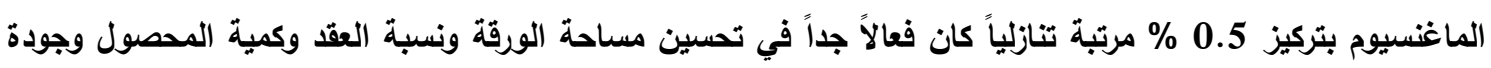
الحبات وأمكن الحصول على أفضل النتائج عند إستخدام العناصر الثلاثة معاً.

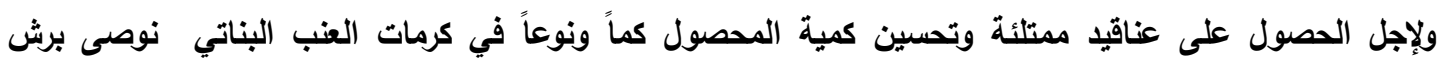

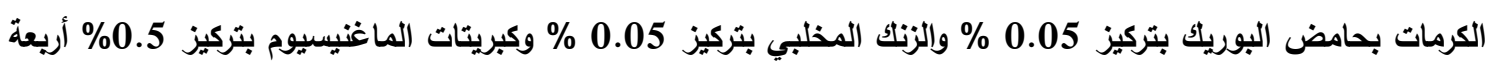

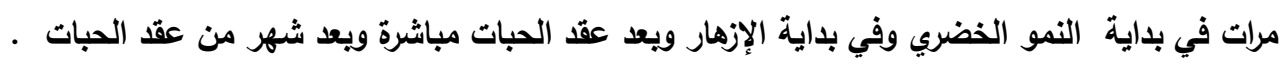


A.M. Hegazy, et al.,

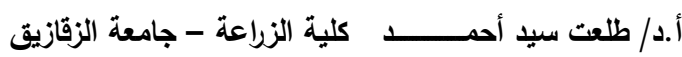

أ.د/ مجدى رابح محمد رابح كلية الزراعة - جامعة المنوفية 